\title{
What can be learned about the deposition and compaction of peat from the Miocene lignite seam exposed in the Chłapowo Cliff on the Polish coast of the Baltic Sea?
}

\author{
Marek Widera \\ Adam Mickiewicz University in Poznań, Institute of Geology; ul. B. Krygowskiego 12, 61-680 Poznań, Poland; \\ e-mail:widera@amu.edu.pl; ORCID ID:0000-0001-5092-2845
}

(C) 2019 Authors. This is an open access publication, which can be used, distributed and reproduced in any medium according to the Creative Commons CC-BY 4.0 License requiring that the original work has been properly cited.

Received: 17 March 2019; accepted: 07 April 2019; first published online: 18 June 2019

\begin{abstract}
This study focuses on discussing the relationship between the accumulation of peat and its compaction in the overbank zone of the Miocene river system. The examined $2^{\text {nd }}$ Lusatian lignite seam is characteristically interbedded with sandy deposits and these are less compressible than peat. Therefore, in favourable conditions such as those found at Chłapowo Cliff (on the Baltic Sea coast in northern Poland), it is possible to identify the effects of an even or uneven lowering of the mire surface, resulting from diversified compaction of the underlying phytogenic beds. The research problem was applied to two examples located close to each other within the lignite seam. The first case shows the accumulation of fresh peat layers of almost equal thickness, while the second one presents a reduction in the thickness of fresh peat beds over the fossilised channel-fill sandy body. Only the latter example allows us to calculate the peat-to-lignite compaction ratio.

The results of the compaction ratio obtained, $C r \approx 7.37$, mean that the youngest, fresh peat layers were compacted at least 7 times, transforming them into lignite beds. However, such a high compaction value, estimated for the top layers of the Miocene mire, cannot be directly taken into account when reconstructing the total thickness of the peat seam prior to covering it with mineral overburden. The published peat-to-lignite compaction ratios, determined using other research methods, for the $2^{\text {nd }}$ Lusatian lignite seam or its stratigraphic equivalents range from 1.7 to 6.0 in most cases, with averages of 2.2 to 4.0. The differences between the data in the literature and the results given in this paper are due to the fact that the process of peat/lignite compaction is ongoing and cumulative.
\end{abstract}

Keywords: Baltic Sea coast, lignite, peat, deposition, compaction, compaction ratio

\section{INTRODUCTION}

Various factors affecting the accumulation of peat, including the compaction process, are taken into account when reconstructing sedimentary palaeoenvironments (e.g. Hurník 1972, Hager et al. 1981, Kasiński 1984, 1985, Hager 1993, Diessel et al. 2000, Michon et al. 2003, Rajchl \& Uličný 2005, Schäfer et al. 2005, Rajchl et al. 2008, van Asselen et al. 2009, Widera 2013a, Schäfer \& Utescher 2014, Kasiński \& Słodkowska 2016, Widera et al. 2019, and references therein). In the case of organic-rich deposits (peat, lignite, coal), the relationship between the original peat thickness and the resulting lignite or coal thickness (termed the compaction ratio), is still relatively misunderstood and controversial. 
Most researchers calculate the compaction ratio using different methods and then extrapolate the obtained results for the whole lignite/coal seam. They do not explain exactly what stage of the mire development and to which beds (basal, top, etc.) their measurements and results concern. Thus, such an approach results in the reconstructed original peat thickness often being over or underestimated. This is best demonstrated by the very wide range of compaction ratio included in the geological literature, which is between 1.1 and 11.0 for lignite from around the world, as the author of this work previously compiled (Widera 2015).

Due to the extremely favourable exposure of the examined lignite seam in the Chłapowo Cliff (Fig. 1), formed by natural geological processes such as sea waves and landslides, it is possible to apply a method of calculating the compaction ratio which has not been previously used for Polish lignite. Hence, the current study aims to (1) demonstrate two different ways of peat growth depending on the amount of the compaction of the underlying layers, (2) estimate the value of the peat-to-lignite compaction ratio, and (3) discuss the possibilities and limitations of the research method applied in this paper.

\section{GEOLOGICAL SETTING}

The study area is located in the northernmost part of Poland, on the Baltic Sea coast. To be more precise, the examined section is situated about $700 \mathrm{~m}$ to the west of the Chłapowo Ravine, also called 'Rudnik', halfway between Władysławowo and Jastrzębia Góra (Fig. 1).

Miocene deposits are exposed in a few segments of the Chlapowo Cliff, at a distance of tens to more than $100 \mathrm{~m}$ and a height of up to $10 \mathrm{~m}$ on both sides of the Chlapowo Ravine. They are separated by numerous landslides, comprising Pleistocene and/or Miocene rocks (e.g. Rudowski 1965, Kramarska 2002, Moskalewicz \& Sokołowski 2014, Uścinowicz et al. 2017). One of the aforementioned exposures is examined in this paper (Figs. 1C, 2A). The Miocene deposits, being in an in situ position, are approximately $30 \mathrm{~m}$ long and up to $7 \mathrm{~m}$ high, relative to the beach level. The Quaternary deposits then rest above the clear erosional boundary, which is made up of glaciogenic Pleistocene sediments, such as till, gravel, sand and mud (Fig. 2A). Both the Miocene and Quaternary deposits are slightly to strongly glaciotectonically disturbed.

In the examined section, the Miocene comprises the lignite bed, which is under and overlain by siliciclastics, often enriched with organic matter. The clastic sediments (mainly sands and muds with carbonaceous intercalations) are horizontally and trough stratified at various scales. They were preliminary interpreted as representing the depositional environment of an anastomosing (Wagner 2007) or meandering river (Moskalewicz \& Sokołowski 2014). The resolution of this issue is not the goal of this research, but it absolutely requires further and more detailed studies.

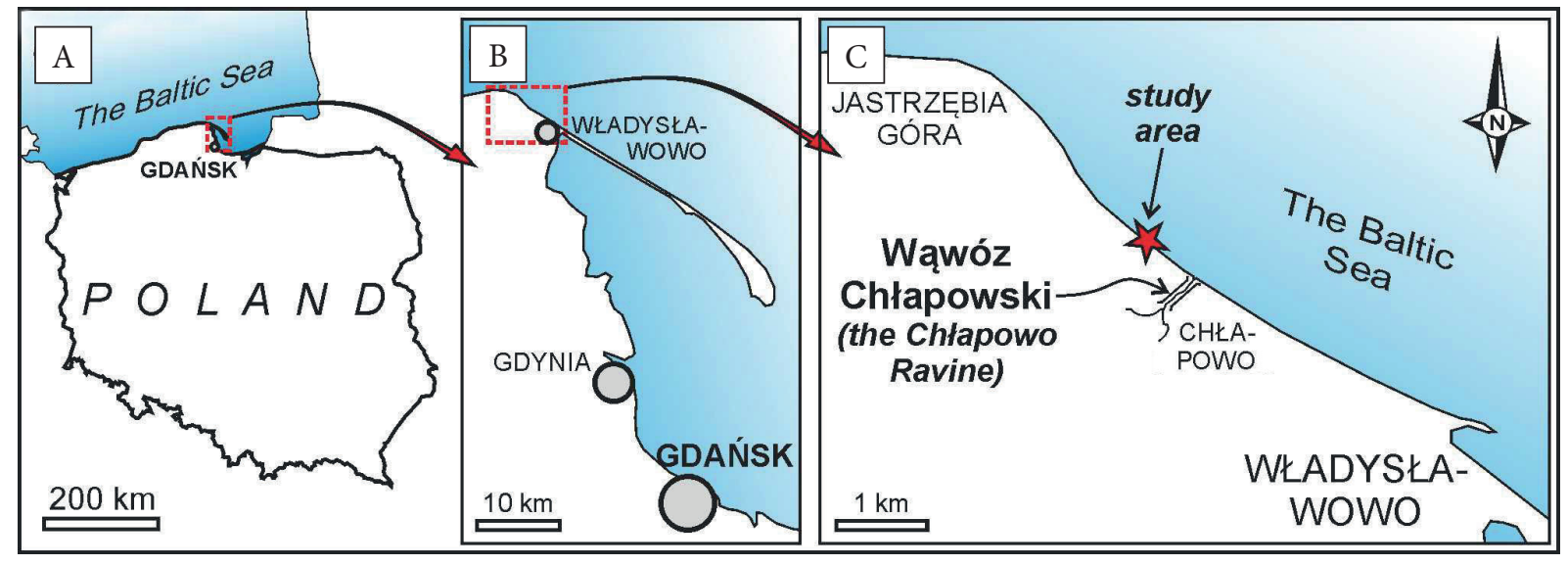

Fig. 1. Location sketch-map of the study area (GPS coordinates: $54^{\circ} 49^{\prime} 04^{\prime \prime} \mathrm{N}, 18^{\circ} 21^{\prime} 27^{\prime \prime} \mathrm{E}$ ) 

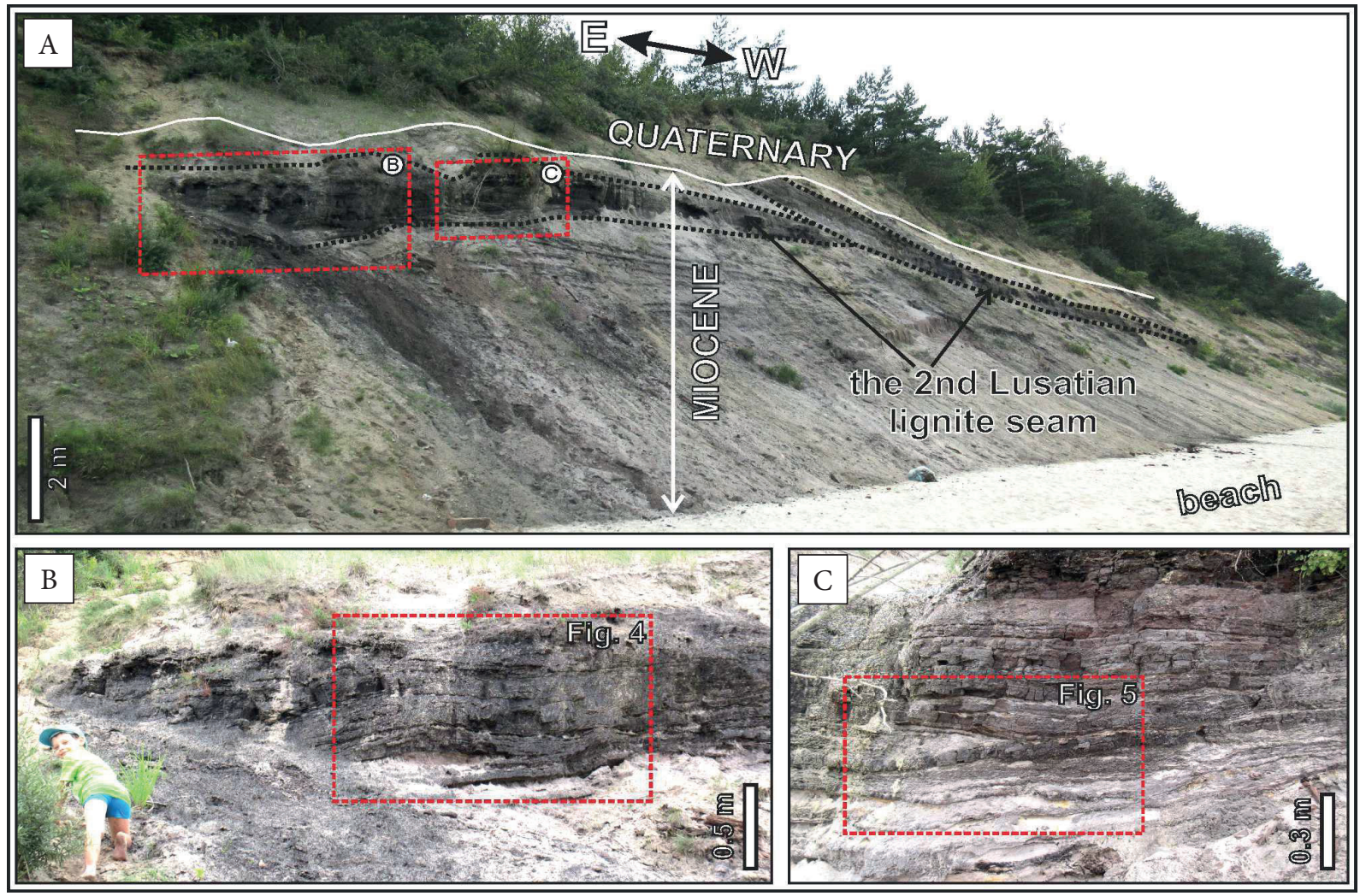

Fig. 2. Part of the Chlapowo Cliff examined in detail. For location see Figure 1: A) broad view of the Miocene outcropped in situ; $B), C)$ close-up views of the studied $2^{\text {nd }}$ Lusatian lignite seam shown in Figures 4 and 5, respectively

Much more important is the lignite seam, which is the subject of the current study. It is an equivalent of the $2^{\text {nd }}$ Lusatian lignite seam, as summarised by Wagner (2007). Thus, it belongs to the upper part of the Ścinawa Formation, which is also called the Krajenka Formation in northern Poland (Piwocki \& Ziembińska-Tworzydło 1997). The age of this lignite seam can, therefore, be determined as being at the turn of the Early to Middle Miocene. Petrographically, the characterised seam consists of detritic and xylodetritic lignite with a horizontal and/or deformed structure, i.e. folded, fractured or faulted (Kwiecińska \& Wagner 1997, Widera 2012, 2016). The lignite beds are commonly interbedded with lenses or thin layers of sand (Fig. 2B, C). This results in high ash content and a relatively low calorific value (Wagner 2007). Nevertheless, the lignite was briefly exploited from the Chłapowo Cliff in 1859 (Rudowski 1965).

\section{MATERIALS AND METHODS}

The majority of the field observations and measurements in the Chłapowo Cliff were carried out in the 2016 research season, with supplementary studies made in 2018. During these two seasons, the photographs included in this work were taken.

According to the classification of Ryer \& Langer (1980), the methods for calculating the peat-to-coal compaction ratio, including the peat-to-lignite one, can be grouped into the following categories: density, inclusions, petrographic and stratigraphic. For more information, the interested reader is directed to the paper where all these methods and the results of their application have been reviewed (Widera 2015). It should be stated here that the research method used in this study belongs to the inclusions method category, as distinguished by Ryer \& Langer (1980).

The inclusions methods are based on a thickness comparison between the originally flat-lying peat beds to the height of the incompressible or less compressible objects, such as coal balls, sandstones and tree trunks (see Widera 2015, his fig. 2). Using this approach, the relative compaction ratio is mostly estimated. Therefore, the results obtained must be recalculated, as in the case of flattened xylites that are quite common components of the lignite seams (Widera 2013b). 
On the basis of two extremely different examples, the research methodology used in this study is explained (Fig. 3). Due to the unique formation of the lignite seam and its exposition being suitable for field research, it is possible to apply the discussed method for Polish lignites for the first time.
The stratification of the examined lignite seam is very clear, often marked by thin sandy laminae, and, hence, the individual lignite layers can be easily observed. Moreover, some lens-shaped sandy bodies, representing the fossilised channel-fill deposits, are also present (cf. Figs. 2B, 2C, 3).
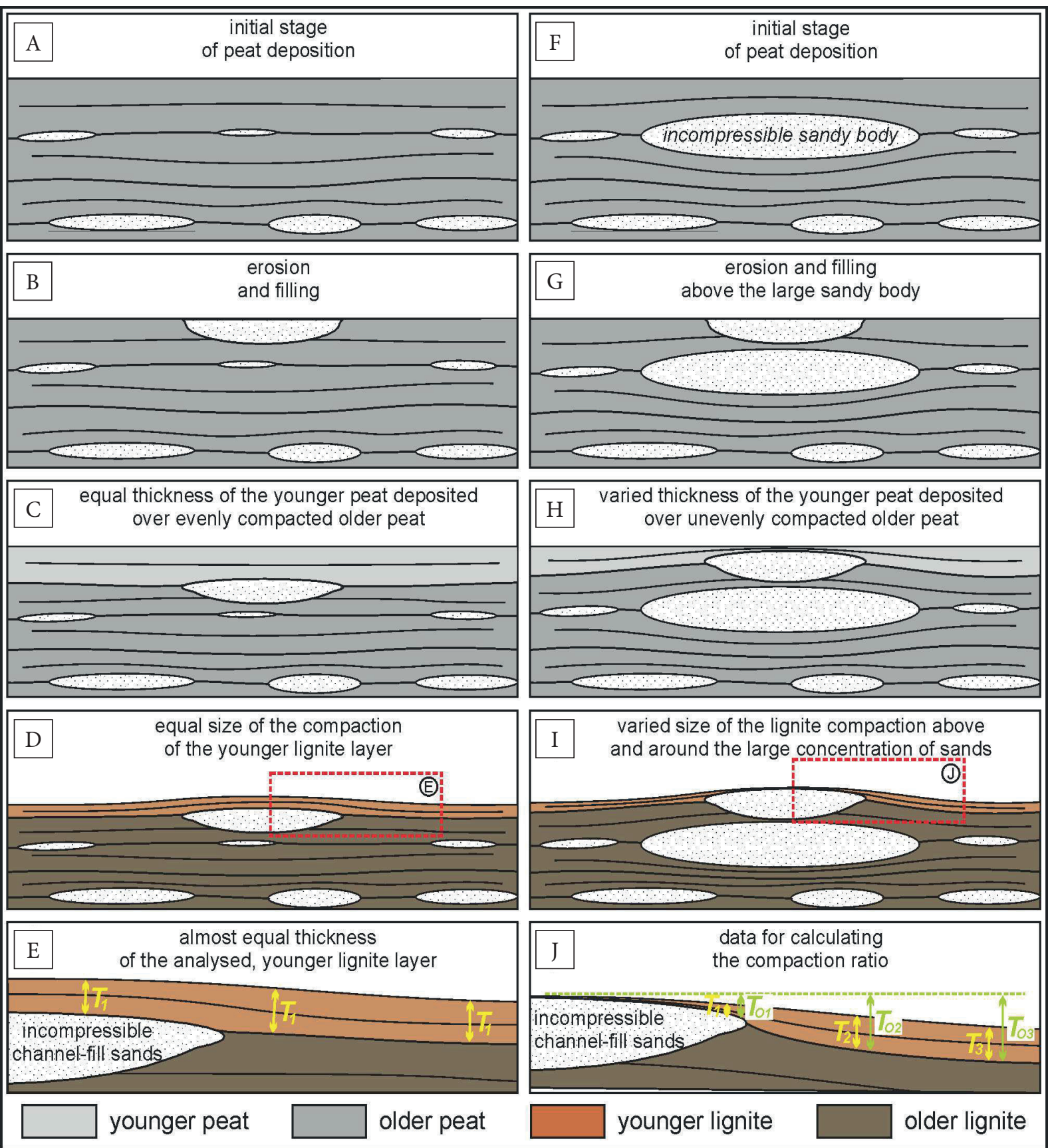

Fig. 3. Idealised models showing different compaction effects of the peat/lignite-bearing seams depending on the lithological composition of the underlying sediments: A)-E) relatively equal lowering of depositional surface caused by even compaction; F)-J) uneven lowering of depositional surface caused by diversified compaction; $T_{01}-T_{03}-$ approximately the original thickness of peat layer, $T_{1}-T_{3}$ - resulting thicknesses of compacted peat/lignite beds 
The first example refers to the situation of an evenly lowering the mire surface (Fig. 3A-E). It takes place when all components, both organic and mineral, are uniformly distributed within the entire peat/lignite seam, resulting in their equal compaction. Thus, the fresh peat layer (later transformed into the lignite bed) is characterised by an almost equal thickness along the analysed layer $T_{1}$ (Fig. 3E). In this case, it is impossible to calculate the compaction ratio because the original peat thickness cannot be reconstructed.

On the contrary, the second example shows the situation when the incompressible components of the peat/lignite seam occupy a significantly larger part of the examined section (Fig. 3F-J). This results in uneven compaction, i.e. it is greater in places where there is less mineral interbedding and smaller in places where relatively thicker and less compressible sand bodies occur in superposition. In such a situation, over the less compressible components of the mire (e.g. sandy bodies, xylites, coaly balls) the thickness of the newly deposited peat bed is very reduced (Fig. $3 \mathrm{H}$ ). As a result, the compacted layer of peat/lignite is characterised by an uneven thickness between the sandy bodies and their surroundings (Fig. 3I). In this case, it is possible to estimate the original peat thicknesses, $T_{01}, T_{02}, T_{03}$, and to measure the actual lignite thickness after compaction, $T_{1}, T_{2}, T_{3}$ (Fig. 3J). The average peatto-lignite compaction ratio, $\mathrm{Cr}$, can easily be calculated according to the following formula (Tab. 1):

$$
C r=\frac{\left[\left(T_{01} / T_{1}\right)+\left(T_{02} / T_{2}\right)+\left(T_{03} / T_{3}\right)\right]}{3} .
$$

\section{Table 1}

Measured thickness of the analysed lignite layer and estimated original peat thickness (shown in Figure 5) used to calculate the peat-to-lignite compaction ratio. For other explanations, see the text

\begin{tabular}{|c|c|c|c|c|c|c|c|}
\cline { 2 - 8 } \multicolumn{1}{c|}{} & \multicolumn{6}{c|}{ Thickness parameters } \\
\cline { 2 - 8 } \multicolumn{1}{c|}{} & $\begin{array}{c}\boldsymbol{T}_{1} \\
{[\mathbf{c m}]}\end{array}$ & $\begin{array}{c}\boldsymbol{T}_{2} \\
{[\mathbf{c m}]}\end{array}$ & $\begin{array}{c}\boldsymbol{T}_{3} \\
{[\mathbf{c m}]}\end{array}$ & $\begin{array}{c}\boldsymbol{T}_{01} \\
{[\mathbf{c m}]}\end{array}$ & $\begin{array}{c}\boldsymbol{T}_{02} \\
{[\mathbf{c m}]}\end{array}$ & $\begin{array}{c}\boldsymbol{T}_{03} \\
{[\mathbf{c m}]}\end{array}$ & $\begin{array}{c}C_{r} \\
{[-]}\end{array}$ \\
\hline $\begin{array}{c}\text { Thickness } \\
\text { measure- } \\
\text { ments }\end{array}$ & 1.4 & 1.6 & 1.3 & 6.9 & 12.8 & 11.8 & 7.37 \\
\hline
\end{tabular}

\section{RESULTS}

In the easternmost segment of the studied section (a part of the Chłapowo Cliff - cf. Figs. 1, 2, 4), the lignite seam is about $1.3 \mathrm{~m}$ thick. The mineral deposits predominate at its base, as evidenced by the presence of continuous and discontinuous sandy layers. Towards the seam roof, the share of mineral interbedding decreases and the share of phytogenic layers significantly increases. However, the lignite stratification is very clear (Fig. 4). This allows a measurement of the thickness of all the lignite beds. They were found to have an almost equal thickness along the entire length of the examined part of the exposure (Fig. 4B).

The interpretation of the situation described above, in the context of deposition and compaction processes, seems to be very instructive. This shows that the average degree of peat/lignite compaction (resulting in lowering of the depositional surface), was equal during the growth of new peat layers.
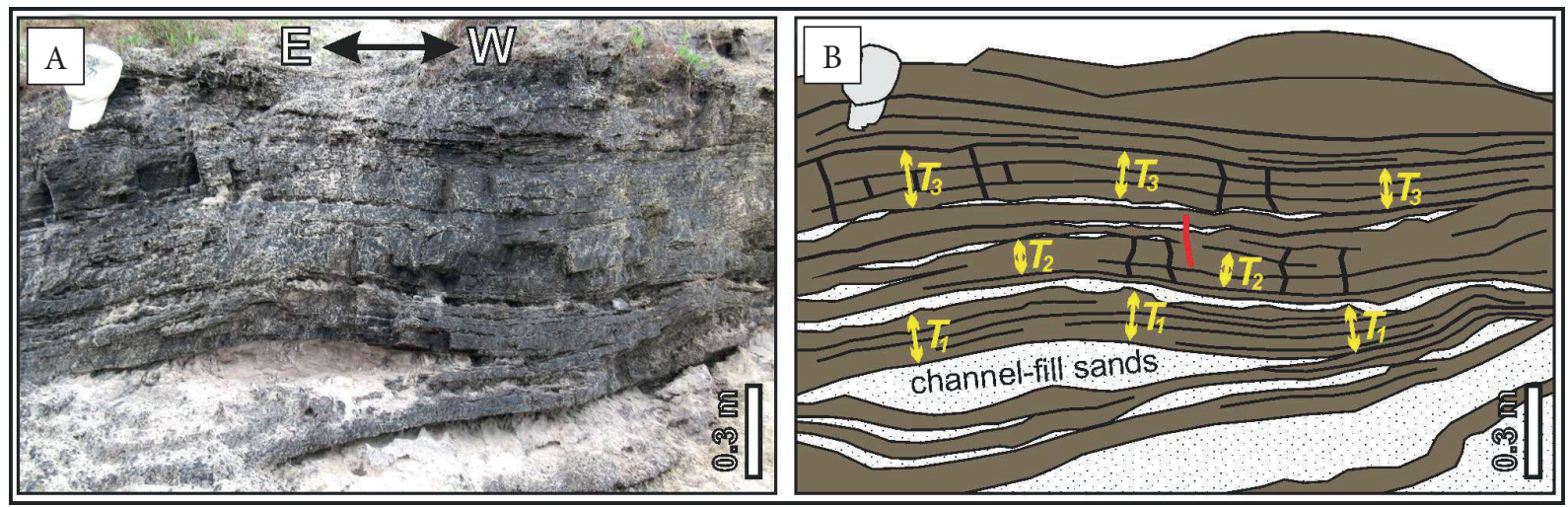

Fig. 4. An example of equal compaction resulting in the steady growth of fresh peat layers - currently, this results in the almost equal thickness of the lignite beds in the upper part of the examined seam. Note, the lignite layers are disturbed (folded, fractured, faulted) postdepositionally, most likely glaciotectonically 

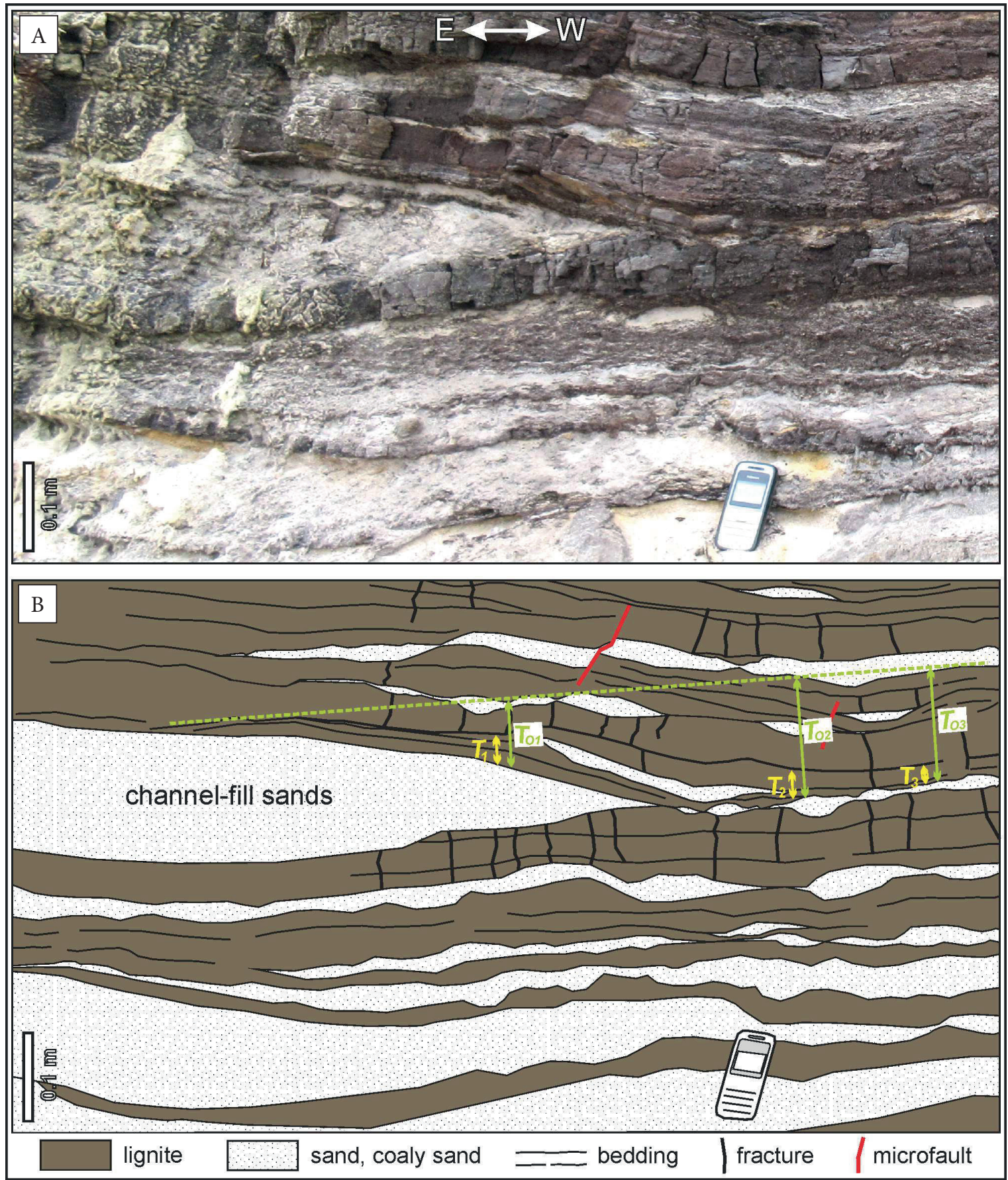

Fig. 5. Example of uneven compaction resulting in varied growth of fresh peat layers - currently uneven thickness of the lignite beds above and in the vicinity of the channel-fill sands. For other explanations, see the text. Note, the deposits are slightly rotated, fractured and faulted, most likely glaciotectonically

Therefore, the measured lignite beds are characterised by almost having the same thickness as $T_{1}, T_{2}$ and $T_{3}$ in Figure 4B. Such a situation is more common, in contrast to the one described below, but unfortunately it does not allow for quantitative calculation of the peat-to-lignite compaction ratio.
The second part of the studied section is located a few metres west of the previous one (Fig. 2). Here, the lignite seam is about $1.0 \mathrm{~m}$ thick and, in general, is texturally and structurally similar to the one shown and discussed above (cf. Figs. 4A, 5A). The most important difference is that the lowest lignite 
bed lies directly on channel-fill sands and has an uneven thickness. It is strongly reduced above the sandy body and is thicker in its vicinity (Fig. 5A).

In such a favourable case, and assuming that the base and the top of the peat layer during its deposition are parallel to each other, it is possible to estimate its original thicknesses, $T_{01}, T_{02}$, $T_{03}$, as shown in Figure 5B. Subsequently, the average thickness of the resulting lignite bed may be measured easily, for example, in three places and then summarised and divided by the number of measurements (Fig. 5). Knowing the estimated original peat thicknesses and the average lignite bed thicknesses the peat-to-lignite compaction ratio, $C_{r}$, can finally be calculated. In the examined case, this ratio is equal to 7.37 (Tab. 1).

\section{DISCUSSION}

The peat-to-lignite compaction ratio for lignite from the Chłapowo Cliff should primarily be compared with the results obtained for the $2^{\text {nd }} \mathrm{Lu}$ satian lignite seams from other parts of Poland and their stratigraphic equivalents from neighbouring countries. All of the compaction ratio values discussed herein were obtained by using stratigraphic methods. Furthermore, it is worth noting that only stratigraphic methods allow a direct quantification of the compaction ratio for the entire lignite seam (Widera 2015). The average peat-to-lignite compaction ratio for lignites from the Krzywin and Złoczew grabens is equal to 2.2 (Kasiński 1984a, 1984b). However, for lignites from the Lubstów Graben the average ratio is 2.5 (Widera 2002, Widera et al. 2007). On the other hand, average values obtained for lignites from the Eger Graben in the Czech Republic were equal to 4.0 (Hurník 1972, Rajchl \& Uličný 2005), while the one estimated for lignites from the Lower Rhine Graben in Germany is approximately 3.0 (Hager et al. 1981, Hager 1993). Thus, all of the averaged values of the compaction ratio are in the range of 2.2 to 4.0 . This simply means that the original thickness of the peat seam, at the moment of the Lower/Middle Miocene mire completion, was 2.2 to 4.0 times higher than the current thickness of the resulting lignite seam.

Finally, the issue of such a high compaction ratio value $\left(C_{r}=7.37\right)$, calculated for the examined lignite from the Polish coast, must be discussed. It must be noted that this value is several times higher than those given above for the majority of European lignites of the same age. Moreover, an average compaction ratio higher than 7.0 is typical, in fact, for bituminous (hard) coals (cf. Widera 2015, his fig. 1). These differences in the values of the reported compaction ratio depend on progressive changes in the properties of peat transforming into lignite. This means that when the uppermost peat layers of the mire were deposited then its lowermost beds, already strongly compacted and coalified $\left(\mathrm{H}_{2} \mathrm{O}\right.$ content $<75 \%$, caloric value $\left.>6.5 \mathrm{MJ} / \mathrm{kg}\right)$, were at the lignite stage. Hence, the question arises as to what compaction ratio was actually calculated during this research? Put simply, compaction was only estimated in this research for several centimetres of fresh peat. Therefore, the obtained results do not allow for the determination of the peat-to-lignite compaction ratio for the entire lignite seam. By analogy with the aforementioned literature data, it can only be said that the formation of $1 \mathrm{~m}$ of lignite, exposed in the Chłapowo Cliff, required approximately $2.2-4.0 \mathrm{~m}$ of peat before being covered by overburden Neogene sediments.

\section{CONCLUSIONS}

The well-exposed, lignite-bearing deposits in the Chłapowo Cliff provided an opportunity to investigate the processes of deposition and peat/lignite compaction. Therefore, the most important results of this study are as follows:

1. The $2^{\text {nd }}$ Lusatian lignite seam outcrops in close proximity to the Chłapowo Ravine, on the Polish coast of the Baltic Sea. This seam was formed as a result of the transformation of Early/Middle Miocene aged peat into lignite. Due to the characteristic textural and structural features of the lignite seam, the depositional environment of the peat is loosely combined with the overbank zone of an anastomosing or meandering river system.

2. Taking into consideration two examples situated close to each other within the same lignite seam, the relationship between the lowering of the depositional surface of the Miocene mire and the compaction of the underlying 
phytogenic deposits is explained. The first example presents even compaction, resulting in an almost even thickness of peat deposit and the currently observed lignite. The second example shows uneven compaction, caused by the varied distribution of sandy bodies within the lignite seam, which leads to the accumulation of an uneven thickness of peat/lignite.

3. In favourable conditions, such as in the second case mentioned above, the peat-to-lignite compaction ratio was calculated as being equal to 7.37. Such a large value is an overestimate, with reference to information contained in the literature; the average values of the compaction ratio for the $2^{\text {nd }}$ Lusatian lignite seam are in the range 2.2 to 4.0 . Therefore, it should be clearly stated that such a high value of compaction ratio only refers to the top layers of the Miocene mire, not to the whole seam. This can be explained by the progressive and cumulative nature of the compaction process of the phytogenic deposits.

The author is grateful to his son, Filip, and Grzegorz Uścinowicz (Marine Geology Branch of the Polish Geological Institute-National Research Institute, Gdanisk, Poland) for their assistance during the fieldwork in 2016 and 2018, respectively. Prof. Andreas Schäfer (Germany) and Dr Karel Mach (Czech Republic) are to be thanked for their valuable comments which have improved the quality of this paper. In addition, Karel Mach's assistance in providing a copy of the original work of Hurnik (1972), as well as some unknown information about the studies of Czech lignites and, most of all, the inspiring exchange of scientific views are all very much appreciated by the author. Last but not least, Alicja Kochman is thanked for her perfect editorial handling.

\section{REFERENCES}

Diessel C., Boyd R., Wadsworth J., Leckie D. \& Chalmers G., 2000. On balanced and unbalanced accommodation/peat accumulation ratios in the Cretaceous coals from Gates Formation, Western Canada, and their sequence-stratigraphic significance. International Journal of Coal Geology, 43, 143-186.

Hager H., 1993. Origin of the Tertiary lignite deposits in the lower Rhine region, Germany. International Journal of Coal Geology, 23, 251-262.
Hager H., Kothen H. \& Spann R., 1981. Zur Setzung der Rheinischen Braunkohle und ihrer klastischen Begleitschichten. Fortschritte in der Geologie von Rheinland und Westfalen, 29, 319-352.

Hurník S., 1972. Koeficient sednutí některých sedimentů v Severočeské hnědouhelné pánvi. Časopis pro mineralogii a geologii, 17/4, 365-372.

Kasiński J.R., 1984a. Tektonika synsedymentacyjna jako czynnik warunkujący sedymentację formacji burowęglowej w zapadliskach tektonicznych na obszarze zachodniej Polski. Przeglad Geologiczny, 32, 260-268.

Kasiński J.R., 1984b. Synsedimentary tectonics as a factor controlling sedimentation of brown-coal formations in tectonic depressions in western Poland. [in:] Borisov V.S. (ed.), Solid fuel mineral deposits: proceedings of the 27th International Geological Congress, Moscow 4-14 August 1984: volume 14, VNU Science Press, Utrecht, 247-279.

Kasiński J.R. \& Słodkowska B., 2016. Factors controlling Cenozoic anthracogenesis in the Polish Lowlands. Geological Quarterly, 60, 959-974.

Kramarska R., 2002. Trzeciorzęd w strefie brzegowej między Jastrzębią Górą a Władysławowem. [in:] Przewodnik LXXIII Zjazdu Polskiego Towarzystwa Geologicznego: Geologia regionu Gdańskiego, Wydawnictwo Państwowego Instytutu Geologicznego, Gdańsk, 69-74.

Kwiecińska B. \& Wagner M., 1997. Typizacja cech jakościowych wegla brunatnego z krajowych złóż według kryteriów petrograficznych $i$ chemiczno-technologicznych dla celów dokumentacji geologicznej złóż oraz obsługi kopalń. Wydawnictwo Centrum Podstawowych Problemów Gospodarki Surowcami Mineralnymi i Energii PAN, Kraków.

Michon L., van Balen R.T., Merle O. \& Pagnier H., 2003. The Cenozoic evolution of the Roer Valley rift system integrated at European scale. Tectonophysics, 367, 101-126.

Moskalewicz D. \& Sokołowski R.J., 2014. Kenozoiczne sekwencje fluwialne w klifie chłapowskim. [in:] Sokołowski R.J. (red.), Ewolucja środowisk sedymentacyjnych regionu Pobrzeża Kaszubskiego, Uniwersytet Gdański. Wydział Oceanografii i Geografii, Gdynia; Uniwersytet Warszawski. Biuro Promocji, Warszawa, 39-49.

Piwocki M. \& Ziembińska-Tworzydło M., 1997. Neogene of the Polish Lowlands - lithostratigraphy and pollen-spore zones. Geological Quarterly, 41, 21-40.

Rajchl M. \& Uličný D., 2005. Depositional record of an avulsive fluvial system controlled by peat compaction (Neogene, Most Basin, Czech Republic). Sedimentology, 52, 601-625.

Rajchl M., Uličný D. \& Mach K., 2008. Interplay between tectonics and compaction in a rift-margin, lacustrine delta system: Miocene of the Eger Graben, Czech Republic. Sedimentology, 55, 1419-1447.

Rudowski S., 1965. Geologia klifu Kępy Swarzewskiej. Rocznik Polskiego Towarzystwa Geologicznego, 35, 301-315.

Ryer T.A. \& Langer A.W., 1980. Thickness change involved in the peat-to-coal transformation for a bituminous coal of Cretaceous age in central Utah. Journal of Sedimentary Petrology, 50, 987-992.

Schäfer A. \& Utescher T., 2014. Origin, sediment fill, and sequence stratigraphy of the Cenozoic Lower Rhine Basin (Germany) interpreted from well logs. Zeitschrift der Deutschen Gesellschaft für Geowissenschaften, 165, 287-314. 
Schäfer A., Utescher T., Klett M. \& Valdivia-Manchego M., 2005. The Cenozoic Lower Rhine Basin - rifting, sedimentation, and cyclic stratigraphy. International Journal of Earth Sciences, 94, 621-639.

Uścinowicz G., Jurys L. \& Szarafin T., 2017. The development of unconsolidated sedimentary coastal cliffs (Pobrzeże Kaszubskie, Northern Poland). Geological Quarterly, 61, 491-501.

van Asselen S., Stouthamer E. \& van Asch Th.W.J., 2009. Effects of peat compaction on delta evolution: a review on processes, responses, measuring and modelling. Earth Science Reviews, 92, 35-51.

Wagner M., 2007. Węglowe osady miocenu Kępy Swarzewskiej na wybrzeżu bałtyckim. Geologia, 33, 69-90.

Widera M., 2002. Próba wyznaczenia współczynnika konsolidacji torfów dla pokładów węgla brunatnego. Przegląd Geologiczny, 50, 42-48.

Widera M., 2012. Macroscopic lithotype characterisation of the $1^{\text {st }}$ Middle-Polish ( $1^{\text {st }}$ Lusatian) Lignite Seam in the Miocene of central Poland. Geologos, 18, 1-11.
Widera M., 2013a. Changes of the lignite seam architecture - a case study from Polish lignite deposits. International Journal of Coal Geology, 114, 60-73.

Widera M., 2013b. Uwagi o wyznaczaniu współczynnika kompakcji ksylitów dla pierwszego środkowopolskiego pokładu węgla brunatnego w centralnej Polsce. Przegląd Geologiczny, 61, 304-310.

Widera M., 2015. Compaction of lignite: a review of methods and results. Acta Geologica Polonica, 65, 367-368.

Widera M., 2016. An overview of lithotype associations forming the exploited lignite seams in Poland. Geologos, $22,213-225$.

Widera M., Jachna-Filipczuk G., Kozula R. \& Mazurek S., 2007. From peat bog to lignite seam: a new method to calculate the consolidation coefficient of lignite seams, Wielkopolska region in central Poland. International Journal of Earth Sciences, 96, 947-955.

Widera M., Stawikowski W. \& Uścinowicz G., 2019. Paleogene-Neogene tectonic evolution of the lignite-rich Szamotuły Graben. Acta Geologica Polonica, 69. DOI: https://doi.org/10.24425/agp.2019.126439 [in press]. 